\title{
Clinical, laboratory, and radiologic findings associated with mortality in COVID-19: A systematic review and meta-analysis
}

\section{Hoo Jung Rhim}

Current Medical Student, Yonsei University Wonju College of Medicine, Wonju, Republic of Korea

Jin Hyun Park

Current Medical Student, Yonsei University Wonju College of Medicine, Wonju, Republic of Korea

Yuna Lee

Current Medical Student, Yonsei University Wonju College of Medicine, Wonju, Republic of Korea

\section{Seung Chan Kwon}

Current Medical Student, Yonsei University Wonju College of Medicine, Wonju, Republic of Korea

\section{Min Gyu Yu}

Current Medical Student, Yonsei University Wonju College of Medicine, Wonju, Republic of Korea

\section{Hunju Lee}

Department of Preventive Medicine, Yonsei University Wonju College of Medicine, Wonju, Republic of Korea

Solam Lee ( $\nabla$ solam@yonsei.ac.kr)

Department of Preventive Medicine, Yonsei University Wonju College of Medicine, Wonju, Republic of Korea

Yeon-Soon Ahn

Department of Preventive Medicine, Yonsei University Wonju College of Medicine, Wonju, Republic of Korea

\section{Systematic Review}

Keywords: COVID-19, mortality, critical, meta-analysis

Posted Date: July 6th, 2020

DOI: https://doi.org/10.21203/rs.3.rs-39877/v1

License: @ (1) This work is licensed under a Creative Commons Attribution 4.0 International License. Read Full License 


\section{Abstract}

Although there has been a surge in reports on coronavirus disease 2019 (COVID-19), the clinical signs and findings associated with fatal outcomes have rarely been studied. This systematic review and meta-analysis aimed to investigate the clinical, laboratory, and radiologic features associated with mortality in COVID-19. A comprehensive search was performed using PubMed, Embase, Web of Science, and other databases including government sources, for articles and reports published until May 1, 2020. We extracted the number of events (mortality and non-mortality) from case series and case-control and cross-sectional studies. Hazard ratios (HR) of each finding were extracted from studies with time-to-outcome analysis. In total, 23 studies met the inclusion criteria. Of them, 18 studies were case-control, cross-sectional, and case series study. Whereas, only 5 studies included time-to-outcome analysis. Male sex, age over 80 years, dyspnea, cardiovascular disease, chronic kidney disease, increased troponin I level, acute respiratory distress syndrome, acute kidney injury, and need of invasive mechanical ventilation were significantly associated with mortality. The identification of patients at higher risk of mortality has an utmost importance to achieve better treatment outcomes. The findings from our study may aid the prioritization in times of severe shortages of medical resources. Further studies analyzing diverse demographic and geographic populations are needed to generalize the findings from this study.

\section{Introduction}

On December 31, 2019, Chinese Health officials informed the World Health Organization (WHO) of 41 cases of unusual pneumonia in Wuhan city, Hubei Province (1). The causal virus was named 'severe acute respiratory syndrome coronavirus 2' (SARS-CoV-2), due to its similarity to the coronavirus responsible for severe acute respiratory syndrome, SARS-CoV. The disease caused by SARS-CoV-2 was later named 'coronavirus disease 2019' (COVID-19). Similar to other Betacoronaviruses, such as Middle East Respiratory Syndrome Coronavirus (MERS-CoV) and SARS-CoV, human-to-human transmission of SARS-CoV-2 has been confirmed $(2,3)$.

COVID-19 is highly contagious and has rapidly spread worldwide (4). On January 30, 2020, WHO declared the novel coronavirus (2019-nCoV) outbreak a public health emergency of international concern. As of May 8, 2020, 3,822,989 cases of COVID-19 have been reported in 213 countries, resulting in 265,084 deaths, leading to the declaration of COVID-19 as a pandemic.

The clinical spectrum of COVID-19 varies from asymptomatic infection to severe illness with respiratory failure, multiple organ failure, and even death $(5,6)$. There are no approved antiviral drugs or vaccines against COVID-19, so supportive care for symptoms like dyspnea and protecting multi-organ function may be the best practice for preventing fatal outcomes (7). For handling the current explosive number of cases with limited medical resources, it is crucial to identify high-risk groups that require intensive treatment and close monitoring (7). Although many studies reported epidemiologic and clinical characteristics of COVID-19, there has rarely been a comprehensive review of the signs and findings that are more frequently observed in patients with fatal outcomes. Therefore, the purpose of this systematic review and meta-analysis was to investigate the clinical, laboratory, and radiological findings of mortality cases comparing to non-mortality cases.

\section{Results}

\section{Study selection and characteristics}

The PRISMA flow diagram is presented in Figure 1. Among 2,012 publications screened, 138 full-text articles were assessed for their eligibility. A total of 23 studies were qualitatively analyzed (Table 1 and Supplementary Table S1)(6, 7, 9-29). In total, 227,856 patients with COVID-19 and 18,038 mortality cases were identified. Of them, 18 studies were case-control, cross-sectional, and case series studies. Whereas, only five studies included time-to-outcome analysis. The Newcastle-Ottawa scale for assessing the quality of casecontrol studies and cohort studies is presented in Supplementary Tables S2 and S3. The summary statistics of the former studies are shown in Figure 2. However, the latter studies could not be meta-analyzed since the findings and their definitions were highly heterogeneous despite the insufficient number of analyzed studies. Therefore, we performed only qualitative synthesis for longitudinal studies reporting HRs (Table 2).

\section{Demographic characteristics and clinical symptoms}


Males (OR, 1.79; 95\% confidence interval [CI], 1.59-2.01) showed higher mortality than females. Among the age groups of COVID-19 patients, age over 80 years (OR, 7.56; $95 \% \mathrm{Cl}, 4.26-13.44)$ and age between 60 and 80 years (OR, 2.37; 95\% Cl, 1.47-3.83) were strongly associated with mortality (Figure 2). Furthermore, age over 65 years (HR 6.07; 95\% $\mathrm{Cl} 1.65-22.35)$ had a higher risk of mortality (Table 2) (14). However, there was a possible publication bias among the studies that reported age under 20 years and age between 40 and 60 years.

Among the clinical symptoms of COVID-19, tachypnea (OR, 8.88; 95\% Cl, 5.64-13.97) and dyspnea (OR, 4.83; 95\% $\mathrm{Cl}, 2.85-8.16)$ showed the strongest association with mortality compared to any other symptoms such as fever $(\mathrm{OR}, 0.99 ; 95 \% \mathrm{Cl}, 0.71-1.38)$ or cough (OR, 1.48; 95\% Cl, 0.67-3.23). However, possible publication bias was detected among the studies reporting fever.

\section{Comorbidities}

Chronic kidney disease (CKD) (OR, 6.32; 95\% Cl, 3.62-11.03) and cardiovascular disease (OR, 5.06; 95\% Cl, 3.54-7.24) showed considerable associations with mortality (Figure 2). Chronic liver disease (OR 1.36; 95\% Cl 0.68-2.74) also exhibited a positive association. Moreover, the presence of one or more comorbidities (HR 2.13; 95\% Cl 1.39-3.26) was strongly associated with mortality (Table 2) (20). However, there was a possible publication bias among the studies reporting diabetes.

\section{Laboratory findings and radiologic findings}

Increased troponin I level ( $\mathrm{Tnl})(\mathrm{OR}, 28.31 ; 95 \% \mathrm{Cl}, 10.55-75.96)$, increased pro-calcitonin level (OR, 12.70; 95\% $\mathrm{Cl}, 6.71-24.03)$, and leukocytosis (OR 6.57; 95\% Cl 2.41-17.91) were more strongly associated with higher mortality than other laboratory findings (Figure 2). Among radiologic findings, patients with bilateral lung involvement in computed tomography (CT) findings (OR, $1.80 ; 95 \% \mathrm{Cl}, 0.79-$ 4.10) had a higher risk of mortality.

\section{Complications and clinical courses}

Some patients developed complications such as acute respiratory distress syndrome (ARDS) or acute kidney injury (AKI) after hospital admission. ARDS (OR, 57.58; 95\% Cl, 16.76-197.80) and AKI (OR, 24.42; 95\% Cl, 8.78-67.93) had a higher risk of mortality (Figure 2). Moreover, acute cardiac injury (HR 3.89; $95 \% \mathrm{Cl} 2.51-6.01)$ was strongly associated with mortality (Table 2) (19). Both the need of invasive mechanical ventilation (OR, 31.30; $95 \% \mathrm{Cl}, 9.99-98.06)$ and the need of non-invasive mechanical ventilation (OR, $14.15 ; 95 \%$ $\mathrm{Cl}, 8.11-24.67)$ were associated with higher mortality. In addition, the mortality rate was higher among patients treated with extracorporeal membrane oxygenation (ECMO) $(\mathrm{OR}, 10.28 ; 95 \% \mathrm{Cl}, 2.62-40.38)$.

\section{Discussion}

This study demonstrated that COVID-19 patients with mortality had distinct characteristics in their clinical, laboratory, and radiologic findings compared to patients with non-mortality. Amongst a few recent systematic reviews on COVID-19, Wang et al. reported the relationship between severity of COVID-19 and comorbidities by analyzing ten studies from China (30); Li et al. focused on analyzing COVID-19 patients' clinical characteristics and overall fatality rate by analyzing six studies from China (31). Zheng et al. analyzed risk factors of critical and mortal cases with 12 studies from China (32). However, previous studies on COVID-19 were limited to the literature from China despite the fact that the Western countries have become the new COVID-19 ground zero (32-34). In addition, the reports from government data source and the studies with time-to-event analysis were rarely analyzed.

\section{Demographic characteristics}

Age is considered the most deterministic factor that affects the clinical outcome in patients with COVID-19. Our data agreed with the previous finding that fatality rate is closely associated with the patients' age (7). The pediatric population (age 0-20 years) reported only two fatality out of 17,070 cases, while young adulthood (age 20-40 years) maintained a minimal mortality rate. The middle-aged population (age 40-60 years) maintained relatively low, but increased, mortality rate. Throughout late adulthood (age 60-80 year), the mortality rate is increased drastically. Patients' ages and COVID-19 mortality risk have a considerable correlation, especially in the 
senior population over 60 years of age. Sex was shown to be either statistically insignificant, or males had significantly higher mortality. This unequal mortality rate between the two sexes may have ensued from the male population having more preexisting chronic diseases or from the older median age, as both were suggested in a Spanish government report (24).

\section{Symptoms}

COVID-19 presented with a wide range of symptoms, with certain manifestations leading to a higher mortality rate. Among respiratory symptoms, patients with tachypnea, dyspnea, or hemoptysis had a significantly higher rate of mortality. However, other upper respiratory symptoms, such as cough and sputum, were not associated with higher mortality. Tachycardia, although statistically insignificant, tended to be associated with greater mortality. In contrast, symptoms associated with other organ systems, such as gastrointestinal symptoms and non-specific symptoms including fatigue and fever, showed minimal associations with mortality. Tachycardia may result from high cytokine levels, which activate cardiac pacemaker cells in the state of infection, or from direct myocardial invasion, as multiple studies have suggested $(35,36)$. Since tachycardia is one of the initial manifestations of acute heart failure, patients presenting tachycardia may need evaluation for acute cardiac injury, a fatal complication of COVID-19.

\section{Comorbidities}

The presence of comorbidity was another significant determinant of mortality. Of commonly reported comorbidities, CKD was related to a strongly increased mortality rate. High risk of mortality in CKD patients may result from an alteration in immune response. Several studies have reported that the combined effects of CKD in cellular immune function lead to a reduced number and malfunction of Tlymphocytes, especially T4 cells (37).

Cardiovascular disease (CVD) and hypertension also increased the risk of mortality. The strong positive relationship between COVID19 severity and the presence of CVD has been suggested $(38,39)$, and our study demonstrated consistent results. History of CVD and atherosclerotic risk factors put an individual at a higher risk of developing acute coronary syndrome in the setting of acute infection (40). Patients with heart failure are more likely to fall into a decompensated state, which leads to other organ damage, including cardiac injury. However, dyspnea and hypoxemia are also common manifestations shared by COVID-19 and heart failure, and therefore can be challenging to distinguish between in a clinical setting. Detailed history taking and diagnostic testing are warranted in patients with suspected CVD.

Patients with diabetes mellitus (DM) had a significantly increased mortality rate in COVID-19, similar to MERS-CoV but to a lesser extent, and those with metabolic syndrome-related disorders had a higher odds of severe infection, ranging from 7.2 to 15.7 (41). These findings may have ensued from DM being an independent risk factor of higher mortality, and the demographic distribution of the mortality group mostly comprised patients with advanced age, which may also have contributed to the high prevalence of DM (42).

\section{Laboratory and radiologic findings}

Multiple blood biomarker concentrations showed significant differences in the mortality group. Increased LDH, a non-specific marker of tissue damage, showed an association with higher mortality rate (43). An increased Tnl concentration, which has excellent specificity in myocardial tissue, was associated with higher mortality (44); this finding can be interpreted as being related to the fatal complications of acute cardiac injury. Alanine aminotransferase (ALT) is relatively specific to liver tissue damage, and patients with increased ALT had a moderately higher mortality.

Increased acute phase reactants (APR) such as pro-calcitonin, C-reactive protein (CRP), and D-dimer were positively associated with mortality (45). All high APRs were associated with higher mortality rates, with pro-calcitonin having the strongest association. Previous studies demonstrated a positive correlation between APR concentration and severity of infection outcome $(46,47)$. Ruan et al. reported that mean CRP concentration was 4-fold higher in the mortality cases than in discharged cases $(p<0.001)(48)$.

Regarding complete blood count findings, leukocytosis and lymphocytosis are the commonly known physiologic responses to viral infection, and lymphopenia was reported in multiple COVID-19 cases $(49,50)$. Lymphopenia was strongly associated with a higher 
chance of death in our findings. Previous studies implied that lymphopenia can have a prognostic value in viral infections (51), and a recent study reported that COVID-19 patients with low blood lymphocyte percentages had poor outcomes $(5,52)$.

Since chest imaging still constitutes a substantial portion of the diagnostic process, as well as being widely used for severity assessment in conventional viral pneumonia, several studies have focused on the radiologic findings of COVID-19 $(1,53)$. Our study demonstrated that the findings of consolidation, ground glass opacity (GGO), and bilateral lung involvement were all associated with a higher mortality rate in different degrees. GGO was the most common feature overall, while consolidation had the greatest association with higher mortality. However, the number of studies that have reported radiologic findings is too low for effective quantitative analysis. Further studies are needed to generalize the observation.

\section{Complication and clinical course}

Acute cardiac injury was a relatively common complication, with strong positive correlation with mortality. Potential causes of acute cardiac injury include the following: multi-organ failure due to cytokine storm, increased myocardial demand and cardiac decompensation, high pro-inflammatory cytokine level and destabilization of atherosclerotic plaques, a higher chance of acute coronary syndrome during infection, and direct myocardial damage (54-56). Although direct viral invasion lacks definitive evidence to date, MERS-CoV was reported to cause acute viral myocarditis (57). Therefore, further investigation is needed considering SARS-CoV2 's striking affinity to the angiotensin-converting enzyme 2 receptor (58).

AKI was one of the most commonly reported complications, with a greater incidence in the mortality group. In AKI, inflammatory cytokines play a key role in the initiation and extension phase of renal injury, thereby leading to renal hemodynamic disturbances (59). An inflammatory cytokine surge indicates severe COVID-19, as previous studies have reported significantly higher mean proinflammatory cytokine levels in the mortality group compared to the controls $(7,48)$. ARDS, another relatively common complication that arises in systemic infection, was also associated with increased mortality. Patients with sepsis or shock experienced the highest mortalities amongst all those with other complications.

Patients who needed invasive mechanical ventilation and non-invasive mechanical ventilation showed an increased mortality rate. Intensive care unit (ICU) admission indicated a 6-fold greater mortality rate. Patients who needed ECMO or continuous renal replacement therapy also had a drastically increased mortality rate, as both are life-saving, last resorts in major organ failure.

\section{Limitations}

The primary limitation of this study is the lack of regional diversity in the studied populations. Although studies from Korea, United States, Italy, and Spain were included in our analysis, many were still from China. Second, some findings were reported by too few studies to be meta-analyzed. Third, some meta-analyzed statistics showed relatively high heterogeneity. However, it had been expected since COVID-19 affects patients of all ages and regions with different availabilities of medical care, and also because of the intrinsic properties of observational studies. Therefore, further studies utilizing restricted data collection processes are necessary as more specific information on individual patients' ages, disease severity, and other information becomes available.

Nevertheless, our study presents a comprehensive review of the clinical, laboratory, and radiologic features associated with mortality of COVID-19, which have rarely been studied. Moreover, a range of data sources, including governmental reports from Western countries, were included in order to obtain widely representative and the most updated results.

\section{Materials And Methods}

\section{Search strategy}

We performed a comprehensive literature search according to the Preferred Reporting Items for Systematic Reviews and MetaAnalyses (PRISMA) reporting guidelines. MEDLINE, Embase, Web of Science, and other official sources, including the government data, the Centers for Disease Control, and Prevention, and the WHO COVID-19 database, were searched. The search keywords were "COVID-19", "2019-nCoV", "coronavirus", "SARS-CoV-2", "fatal", "mortality", and "clinical manifestations". Our initial literature search included the studies published until March 30, 2020. However, since research on COVID-19 is increasingly being reported, an 
additional literature search was performed for the studies published until May 1, 2020, using the same databases and search strategy. Any articles written in English, Korean, and Spanish were included because of the authors' proficiency in these languages.

\section{Study selection}

Three main reviewers (H.R, J.P, and Y.L) independently evaluated the titles and abstracts of retrieved studies. Any disagreements between the reviewers regarding the suitability of the studies were discussed with two other reviewers (S.K and M.Y) and resolved by consensus. All observational studies on COVID-19 that investigated both patients (with mortality and without mortality) were included, whereas the followings were excluded: 1) non-research articles, 2) studies that reported cases which did not fulfill the diagnostic criteria of WHO interim guidance, 3 ) studies that only investigated either mortality or non-mortality cases (noncomparability), and 4) studies with insufficient sample size $(n<10)$.

\section{Data extraction and quality assessment}

Data regarding publication details, population demographics, clinical manifestations, comorbidities, laboratory findings, radiologic findings, complications, and clinical courses were extracted from each study. The number of events and total observations in both the mortality cases and the non-mortality cases for any outcomes associated with clinical, laboratory, and radiologic features were extracted from case-control, cross-sectional, and case series studies. For cohort studies and any other studies with time-to-outcome analysis, hazard ratios (HR) for each finding were directly extracted. The Newcastle-Ottawa scale for assessing the quality of casecontrol studies and cohort studies was used for the assessment of the analyzed studies. Finally, the articles with adequate quality (score $\geq 5$ ) were included in the quantitative meta-analysis (8).

\section{Data synthesis and outcomes}

For case-control, cross-sectional, and case-series studies, we calculated the odds ratio (OR) as a statistic to summarize the characteristic findings of the mortality cases compared to the non-mortality cases. Whereas the HRs obtained from each study were to be meta-analyzed with time-to-outcome analysis. A random-effects model was used to conduct the meta-analysis because a significant heterogeneity between the included studies was expected. The $P$ statistic was used to estimate and quantify heterogeneity between the studies. Egger's linear regression test was performed to evaluate publication bias. The analysis was performed using $R$ version 3.5.0 ( $\mathrm{R}$ foundation for statistical computing). A $P$ value $<0.05$ was considered statistically significant.

\section{Declarations}

\section{Code and data availability}

The final datasheet for extraction, the program code used for the quantitative synthesis, and the forest plots for individual analyses can be accessed at our public repository: http://dx.doi.org/10.17632/h55cyhs82c.1

\section{Acknowledgments}

None

\section{Author Contributions}

Rhim and S.L designed and conceptualized the study. Ahn supervised the project. Rhim, Park, Y.L, Kwon, Yu, H.L and S.L performed the calculations and data analyses. Rhim, park, Y.L drafted the manuscript. All authors revised the manuscript. S.L and Ahn validated the results. All authors finally reviewed the manuscript.

\section{Corresponding Author}




\section{Additional Information}

The authors declare no competing interests.

\section{References}

1.Commission WMH: Report of clustering pneumonia of unknown etiology in Wuhan City. Accessed March 31, 2020. Available at: http://wjw.wuhan.gov.cn/front/web/showDetail/2019123108989.

2.Chan JF, Yuan S, Kok KH, To KK, et al: A familial cluster of pneumonia associated with the 2019 novel coronavirus indicating personto-person transmission: a study of a family cluster. Lancet 2020; 395(10223):514-523

3.Guo YR, Cao QD, Hong ZS, Tan YY, et al: The origin, transmission and clinical therapies on coronavirus disease 2019 (COVID-19) outbreak - an update on the status. Mil Med Res 2020; 7(1):11

4.Surveillances V: The epidemiological characteristics of an outbreak of 2019 novel coronavirus diseases (COVID-19)-China, 2020. China CDC Weekly 2020; 2(8):113-122

5.Chen N, Zhou M, Dong X, Qu J, et al: Epidemiological and clinical characteristics of 99 cases of 2019 novel coronavirus pneumonia in Wuhan, China: a descriptive study. Lancet 2020; 395(10223):507-513

6.Zhou F, Yu T, Du R, Fan G, et al: Clinical course and risk factors for mortality of adult inpatients with COVID-19 in Wuhan, China: a retrospective cohort study. Lancet 2020; 395(10229):1054-1062

7.Chen T, Wu D, Chen H, Yan W, et al: Clinical characteristics of 113 deceased patients with coronavirus disease 2019: retrospective study. Bmj 2020; 368:m1091

8.Stang A: Critical evaluation of the Newcastle-Ottawa scale for the assessment of the quality of nonrandomized studies in metaanalyses. European journal of epidemiology 2010; 25(9):603-605

9.Cao J, Tu WJ, Cheng W, Yu L, et al: Clinical Features and Short-term Outcomes of 102 Patients with Corona Virus Disease 2019 in Wuhan, China. Clin Infect Dis 2020 DOI: 10.1093/cid/ciaa243.

10.Chen T, Dai Z, Mo P, Li X, et al: Clinical characteristics and outcomes of older patients with coronavirus disease 2019 (COVID-19) in Wuhan, China (2019): a single-centered, retrospective study. J Gerontol A Biol Sci Med Sci 2020 DOI: 10.1093/gerona/glaa089.

11.Cheng Y, Luo R, Wang K, Zhang M, et al: Kidney disease is associated with in-hospital death of patients with COVID-19. Kidney Int 2020; 97(5):829-838

12.Deng Y, Liu W, Liu K, Fang YY, et al: Clinical characteristics of fatal and recovered cases of coronavirus disease 2019 (COVID-19) in Wuhan, China: a retrospective study. Chin Med J (Engl) 2020 DOI: 10.1097/cm9.0000000000000824.

13.Du RH, Liang LR, Yang CQ, Wang W, et al: Predictors of Mortality for Patients with COVID-19 Pneumonia Caused by SARS-CoV-2: A Prospective Cohort Study. Eur Respir J 2020 DOI: 10.1183/13993003.00524-2020.

14.Feng Y, Ling Y, Bai T, Xie Y, et al: COVID-19 with Different Severity: A Multi-center Study of Clinical Features. Am J Respir Crit Care Med 2020 DOI: 10.1164/rccm.202002-04450C.

15.Grasselli G, Zangrillo A, Zanella A, Antonelli M, et al: Baseline Characteristics and Outcomes of 1591 Patients Infected With SARSCoV-2 Admitted to ICUs of the Lombardy Region, Italy. Jama 2020 DOI: 10.1001/jama.2020.5394.

16. Hu H, Yao N, Qiu Y: Comparing rapid scoring systems in mortality prediction of critical ill patients with novel coronavirus disease. Acad Emerg Med 2020 DOI: 10.1111/acem.13992. 
17.KCDC: Cases of COVID-19 in Korea (as of 00 on 4.30.). Accessed April 30, 2020 Available at: http://ncov.mohw.go.kr/bdBoardList_Real.do?brdld = 1\&brdGubun $=11 \&$ ncvContSeq $=$ \&contSeq $=$ \&board_id $=$ \&gubun $=$.

18.Li J, Wang X, Chen J, Zhang H, et al: Association of Renin-Angiotensin System Inhibitors With Severity or Risk of Death in Patients With Hypertension Hospitalized for Coronavirus Disease 2019 (COVID-19) Infection in Wuhan, China. JAMA Cardio/ 2020 DOI: 10.1001/jamacardio.2020.1624.

19.Li X, Xu S, Yu M, Wang K, et al: Risk factors for severity and mortality in adult COVID-19 inpatients in Wuhan. J Allergy Clin Immunol 2020 DOI: 10.1016/j.jaci.2020.04.006.

20.Liang WH, Guan WJ, Li CC, Li YM, et al: Clinical characteristics and outcomes of hospitalised patients with COVID-19 treated in Hubei (epicenter) and outside Hubei (non-epicenter): A Nationwide Analysis of China. Eur Respir J 2020 DOI: 10.1183/13993003.00562-2020.

21.Richardson S, Hirsch JS, Narasimhan M, Crawford JM, et al: Presenting Characteristics, Comorbidities, and Outcomes Among 5700 Patients Hospitalized With COVID-19 in the New York City Area. Jama 2020 DOI: 10.1001/jama.2020.6775.

22.Ruan Q, Yang K, Wang W, Jiang L, et al: Correction to: Clinical predictors of mortality due to COVID-19 based on an analysis of data of 150 patients from Wuhan, China. Intensive Care Med 2020 DOI: 10.1007/s00134-020-06028-z.

23.Shi S, Qin M, Shen B, Cai Y, et al: Association of Cardiac Injury With Mortality in Hospitalized Patients With COVID-19 in Wuhan, China. JAMA Cardiol 2020 DOI: 10.1001/jamacardio.2020.0950.

24.SiVies: Informe COVID-19 $n^{\circ} 27.30$ de abril de 2020. Accessed April 30, 2020. Available at: https://www.isciii.es/QueHacemos/Servicios/VigilanciaSaludPublicaRENAVE/EnfermedadesTransmisibles/Paginas/InformesCOVID19.aspx.

25.Wu C, Chen X, Cai Y, Xia J, et al: Risk Factors Associated With Acute Respiratory Distress Syndrome and Death in Patients With Coronavirus Disease 2019 Pneumonia in Wuhan, China. JAMA Intern Med 2020 DOI: 10.1001/jamainternmed.2020.0994.

26.Xu B, Fan CY, Wang AL, Zou YL, et al: Suppressed T cell-mediated immunity in patients with COVID-19: A clinical retrospective study in Wuhan, China. J Infect 2020 DOI: 10.1016/j.jinf.2020.04.012.

27.Yang X, Yu Y, Xu J, Shu H, et al: Clinical course and outcomes of critically ill patients with SARS-CoV-2 pneumonia in Wuhan, China: a single-centered, retrospective, observational study. Lancet Respir Med 2020 DOI: 10.1016/S2213-2600(20)30079-5.

28.Yuan M, Yin W, Tao Z, Tan W, et al: Association of radiologic findings with mortality of patients infected with 2019 novel coronavirus in Wuhan, China. PLoS One 2020; 15(3):e0230548

29.Zhang J, Wang X, Jia X, Li J, et al: Risk factors for disease severity, unimprovement, and mortality in COVID-19 patients in Wuhan, China. Clin Microbiol Infect 2020 DOI: 10.1016/j.cmi.2020.04.012.

30.Wang B, Li R, Lu Z, Huang Y: Does comorbidity increase the risk of patients with COVID-19: evidence from meta-analysis. Aging (Albany NY) 2020; 12 DOI: 10.18632/aging.103000.

31.Li LQ, Huang T, Wang YQ, Wang ZP, et al: COVID-19 patients' clinical characteristics, discharge rate, and fatality rate of metaanalysis. J Med Virol 2020 DOI: 10.1002/jmv.25757.

32.Zheng Z, Peng F, Xu B, Zhao J, et al: Risk factors of critical \& mortal COVID-19 cases: A systematic literature review and metaanalysis. J Infect 2020 DOI: 10.1016/j.jinf.2020.04.021.

33.Rodriguez-Morales AJ, Cardona-Ospina JA, Gutierrez-Ocampo E, Villamizar-Pena R, et al: Clinical, laboratory and imaging features of COVID-19: A systematic review and meta-analysis. Travel Med Infect Dis 2020:101623

34.Cao Y, Liu X, Xiong L, Cai K: Imaging and clinical features of patients with 2019 novel coronavirus SARS-CoV-2: A systematic review and meta-analysis. J Med Virol 2020 DOI: 10.1002/jmv.25822. 
35.Zhu H, Rhee JW, Cheng P, Waliany S, et al: Cardiovascular Complications in Patients with COVID-19: Consequences of Viral Toxicities and Host Immune Response. Curr Cardiol Rep 2020; 22(5):32

36.Nalivaiko E: Tachycardia during fever: is it neural or humoral? Am J Physiol Regul Integr Comp Physio/ 2006; 290(6):R1750; author reply R1751

37.Ren W, Pan H, Wang P, Lan L, et al: Clinical analysis of pulmonary infection in hemodialysis patients. Exp Ther Med 2014; 7(6):1713-1717

38.Wang D, Hu B, Hu C, Zhu F, et al: Clinical Characteristics of 138 Hospitalized Patients With 2019 Novel Coronavirus-Infected Pneumonia in Wuhan, China. Jama 2020; 323(11):1061-1069

39.Wu Z, McGoogan JM: Characteristics of and Important Lessons From the Coronavirus Disease 2019 (COVID-19) Outbreak in China: Summary of a Report of 72314 Cases From the Chinese Center for Disease Control and Prevention. Jama 2020 DOI: 10.1001/jama.2020.2648.

40.Smeeth L, Thomas SL, Hall AJ, Hubbard R, et al: Risk of myocardial infarction and stroke after acute infection or vaccination. $N$ Engl J Med 2004; 351(25):2611-2618

41.Badawi A, Ryoo SG: Prevalence of comorbidities in the Middle East respiratory syndrome coronavirus (MERS-CoV): a systematic review and meta-analysis. Int J Infect Dis 2016; 49:129-133

42.Hu C, Jia W: Diabetes in China: Epidemiology and Genetic Risk Factors and Their Clinical Utility in Personalized Medication. Diabetes 2018; 67(1):3-11

43.Su Y, Ju MJ, Ma JF, Tu GW, et al: Lactate dehydrogenase as a prognostic marker of renal transplant recipients with severe community-acquired pneumonia: a 10-year retrospective study. Ann Trans/ Med 2019; 7(22):660

44.Apple FS: Tissue specificity of cardiac troponin I, cardiac troponin T and creatine kinase-MB. Clin Chim Acta 1999; 284(2):151-159 45.Lelubre C, Anselin S, Zouaoui Boudjeltia K, Biston P, et al: Interpretation of C-reactive protein concentrations in critically ill patients. Biomed Res Int 2013; 2013:124021

46.Wannamethee SG, Whincup PH, Lennon L, Papacosta O, et al: Associations between fibrin D-dimer, markers of inflammation, incident self-reported mobility limitation, and all-cause mortality in older men. J Am Geriatr Soc 2014; 62(12):2357-2362

47.Castelli GP, Pognani C, Cita M, Stuani A, et al: Procalcitonin, C-reactive protein, white blood cells and SOFA score in ICU: diagnosis and monitoring of sepsis. Minerva Anestesiol 2006; 72(1-2):69-80

48.Ruan QR, Yang K, Wang WX, Jiang LY, et al: Clinical predictors of mortality due to COVID-19 based on an analysis of data of 150 patients from Wuhan, China. Intensive Care Medicine DOI: 10.1007/s00134-020-05991-x.

49.Li K, Wu J, Wu F, Guo D, et al: The Clinical and Chest CT Features Associated with Severe and Critical COVID-19 Pneumonia. Invest Radio/ 2020 DOI: 10.1097/RLI.0000000000000672.

50.Huang C, Wang Y, Li X, Ren L, et al: Clinical features of patients infected with 2019 novel coronavirus in Wuhan, China. Lancet 2020; 395(10223):497-506

51.Boonnak K, Vogel L, Feldmann F, Feldmann H, et al: Lymphopenia associated with highly virulent H5N1 virus infection due to plasmacytoid dendritic cell-mediated apoptosis of T cells. J Immunol 2014; 192(12):5906-5912

52.Tan L, Wang Q, Zhang D, Ding J, et al: Lymphopenia predicts disease severity of COVID-19: a descriptive and predictive study. Signal Transduct Target Ther 2020; 5:33

53.Guan CS, Lv ZB, Yan S, Du YN, et al: Imaging Features of Coronavirus disease 2019 (COVID-19): Evaluation on Thin-Section CT. Acad Radiol 2020; 27(5):609-613 DOI: 10.1016/j.acra.2020.03.002. 
54.Bansal M: Cardiovascular disease and COVID-19. Diabetes Metab Syndr 2020; 14(3):247-250

55.Bonow RO, Fonarow GC, O'Gara PT, Yancy CW: Association of Coronavirus Disease 2019 (COVID-19) With Myocardial Injury and Mortality. JAMA Cardiol 2020 DOI: 10.1001/jamacardio.2020.1105.

56.Guo T, Fan Y, Chen M, Wu X, et al: Cardiovascular Implications of Fatal Outcomes of Patients With Coronavirus Disease 2019 (COVID-19). JAMA Cardio/ 2020 DOI: 10.1001/jamacardio.2020.1017.

57.Alhogbani T: Acute myocarditis associated with novel Middle east respiratory syndrome coronavirus. Ann Saudi Med 2016; 36(1):78-80

58.Zhang H, Penninger JM, Li Y, Zhong N, et al: Angiotensin-converting enzyme 2 (ACE2) as a SARS-CoV-2 receptor: molecular mechanisms and potential therapeutic target. Intensive Care Med 2020; 46(4):586-590

59.Akcay A, Nguyen Q, Edelstein CL: Mediators of inflammation in acute kidney injury. Mediators Inflamm 2009; 2009:137072

\section{Tables}

Table 1. Characteristics of the included studies on coronavirus disease 2019 


\begin{tabular}{|c|c|c|c|c|c|}
\hline Country & Study design & $\begin{array}{l}\text { Study } \\
\text { population } \\
\text { (n) }\end{array}$ & $\begin{array}{l}\text { Age } \pm \\
\text { SD } \\
\text { (years) / } \\
\text { Female } \\
\text { (n) }\end{array}$ & $\begin{array}{l}\text { Study population (n) / Age } \pm \\
\text { SD in mortality group }\end{array}$ & $\begin{array}{l}\text { Study population (n) / Age } \pm \text { SD } \\
\text { in non-mortality group }\end{array}$ \\
\hline \multirow[t]{2}{*}{ China } & $\begin{array}{l}\text { Retrospective cohort } \\
\text { study }\end{array}$ & 191 & $\begin{array}{l}56(46- \\
67)^{\mathrm{a} /}\end{array}$ & $54 / 69(63-76)^{a}$ & $137 / 52(45-58)^{a}$ \\
\hline & & & 72 & & \\
\hline \multirow[t]{2}{*}{ Italy } & $\begin{array}{l}\text { Retrospective case } \\
\text { series study }\end{array}$ & 1581 & $\begin{array}{l}63(56- \\
70)^{\mathrm{a}} /\end{array}$ & 405 / NA & 1176 / NA \\
\hline & & & 287 & & \\
\hline \multirow[t]{2}{*}{ China } & Cohort study & 102 & $\begin{array}{l}54(37- \\
67)^{a} /\end{array}$ & $17 / 72(63-81)^{a}$ & $85 / 53(47-66)^{a}$ \\
\hline & & & 49 & & \\
\hline \multirow[t]{2}{*}{ China } & Retrospective study & 27 & $\begin{array}{l}60(47- \\
69)^{\mathrm{a}} /\end{array}$ & $10 / 68(63-73)^{a}$ & $17 / 55(35-60)^{a}$ \\
\hline & & & 15 & & \\
\hline \multirow[t]{2}{*}{ China } & $\begin{array}{l}\text { Prospective cohort } \\
\text { study }\end{array}$ & 179 & $\begin{array}{l}57.6 \pm \\
13.7 /\end{array}$ & $21 / 70.2 \pm 7.7$ & $158 / 56.0 \pm 13.5$ \\
\hline & & & 82 & & \\
\hline \multirow[t]{2}{*}{ Spain } & Government report & 203715 & $\begin{array}{l}61(46- \\
78)^{\mathrm{a} /}\end{array}$ & 15873 / 83 (75-88) & 187842 / $59(45-75)$ \\
\hline & & & 113045 & & \\
\hline \multirow[t]{2}{*}{ China } & $\begin{array}{l}\text { Retrospective case } \\
\text { series study }\end{array}$ & 274 & $\begin{array}{l}62(44- \\
70)^{\mathrm{a}} /\end{array}$ & $113 / 68(62-77)^{a}$ & $161 / 51(37-66)^{a}$ \\
\hline & & & 103 & & \\
\hline \multirow[t]{2}{*}{ China } & Case series study & 55 & $\begin{array}{l}74.0 \\
(65-91)^{a} \\
/\end{array}$ & $19 / 77$ & $36 / 72$ \\
\hline & & & 40 & & \\
\hline \multirow[t]{2}{*}{ China } & $\begin{array}{l}\text { Retrospective } \\
\text { observational study }\end{array}$ & 52 & $\begin{array}{l}59.7 \pm \\
13.3 /\end{array}$ & $32 / 64.6 \pm 11.2$ & $20 / 51.9 \pm 12.9$ \\
\hline & & & 17 & & \\
\hline China & Retrospective study & 225 & $\begin{array}{l}\text { NA / } \\
101\end{array}$ & $109 / 69(62-74)^{a}$ & $116 / 40(33-57)^{a}$ \\
\hline Korea & Government report & 10774 & $\begin{array}{l}\text { NA / } \\
6418\end{array}$ & 248 / NA & 10526 / NA \\
\hline China & Retrospective study & 150 & NA / 48 & $68 / 67(15-81)^{a}$ & $82 / 50(44-81)^{a}$ \\
\hline \multirow[t]{2}{*}{ China } & $\begin{array}{l}\text { Retrospective cohort } \\
\text { study }\end{array}$ & 201 & $\begin{array}{l}51(43- \\
60)^{\mathrm{a} /}\end{array}$ & 44 / $68.5(49.3-75)^{a}$ & 157 / NA \\
\hline & & & 73 & & \\
\hline China & $\begin{array}{l}\text { Retrospective cohort } \\
\text { study, multicenter }\end{array}$ & 337 & NA / NA & $16 / N A$ & 321 / NA \\
\hline \multirow[t]{2}{*}{ China } & $\begin{array}{l}\text { Retrospective cohort } \\
\text { study }\end{array}$ & 1590 & $\begin{array}{l}48.9 \pm \\
16.3 /\end{array}$ & 50 / NA & 1540 / NA \\
\hline & & & 674 & & \\
\hline
\end{tabular}

Page $11 / 17$ 


\begin{tabular}{|c|c|c|c|c|c|}
\hline Country & Study design & $\begin{array}{l}\text { Study } \\
\text { population } \\
\text { (n) }\end{array}$ & $\begin{array}{l}\text { Age } \pm \\
\text { SD } \\
\text { (years) / } \\
\text { Female } \\
\text { (n) }\end{array}$ & $\begin{array}{l}\text { Study population (n) / Age } \pm \\
\text { SD in mortality group }\end{array}$ & $\begin{array}{l}\text { Study population (n) / Age } \pm \text { SD } \\
\text { in non-mortality group }\end{array}$ \\
\hline \multirow[t]{2}{*}{ China } & $\begin{array}{l}\text { Retrospective cohort } \\
\text { study }\end{array}$ & 416 & $\begin{array}{l}64(21- \\
95)^{\mathrm{a}} /\end{array}$ & 57 / NA & 359 / NA \\
\hline & & & 211 & & \\
\hline \multirow[t]{2}{*}{ China } & $\begin{array}{l}\text { Retrospective cohort } \\
\text { study }\end{array}$ & 701 & $\begin{array}{l}63(50- \\
71)^{\mathrm{a}} /\end{array}$ & 113 / NA & 588 / NA \\
\hline & & & 334 & & \\
\hline \multirow[t]{2}{*}{ China } & $\begin{array}{l}\text { Retrospective cohort } \\
\text { study }\end{array}$ & 269 & $\begin{array}{l}65(54- \\
72)^{\mathrm{a}} /\end{array}$ & 87 / NA & $181 / \mathrm{NA}$ \\
\hline & & & 134 & & \\
\hline \multirow[t]{2}{*}{ China } & Retrospective study & 105 & $\begin{array}{l}60.8 \pm \\
16.3 /\end{array}$ & $19 / 75.1 \pm 12.9$ & $86 / 57.7 \pm 15.3$ \\
\hline & & & 51 & & \\
\hline \multirow[t]{2}{*}{ China } & $\begin{array}{l}\text { Retrospective case } \\
\text { series study }\end{array}$ & 362 & $\begin{array}{l}66(59- \\
73)^{\mathrm{a}} /\end{array}$ & $77 / 72(64.5-82)^{a}$ & $285 / 65(57.5-71)^{a}$ \\
\hline & & & 173 & & \\
\hline \multirow[t]{2}{*}{ US } & Case series study & 5700 & $\begin{array}{l}63(52- \\
75)^{\mathrm{a}} /\end{array}$ & 553 / NA & 5147 / NA \\
\hline & & & 2263 & & \\
\hline \multirow[t]{2}{*}{ China } & $\begin{array}{l}\text { Retrospective } \\
\text { observational study }\end{array}$ & 187 & $\begin{array}{l}62 \\
(48.5- \\
71)^{a} /\end{array}$ & $28 / 73(68-77.2)^{a}$ & 159 / NA \\
\hline & & & 84 & & \\
\hline \multirow[t]{2}{*}{ China } & $\begin{array}{l}\text { Retrospective cohort } \\
\text { study }\end{array}$ & 663 & $\begin{array}{l}55.6 \\
(44- \\
69)^{\mathrm{a}} /\end{array}$ & $25 / 67.1(61-78)^{\mathrm{a}}$ & $638 / 59.1(43-68)^{a}$ \\
\hline & & & 342 & & \\
\hline
\end{tabular}

${ }^{\mathrm{a}}$ Expressed as median age (interquartile range)

Table 2. Qualitative synthesis of studies with time-to-outcome analysis 


\begin{tabular}{|c|c|c|c|c|c|}
\hline Study & Study design & $\begin{array}{l}\text { Study population (n) / } \\
\text { Mean age } \pm \text { SD } \\
\text { (years) / Female } \\
\text { patients (n) }\end{array}$ & $\begin{array}{l}\text { Study population } \\
\text { (n) / Mean age in } \\
\text { mortality group } \\
\text { (years) }\end{array}$ & $\begin{array}{l}\text { Study population ( } n \text { ) } \\
\text { / Mean age in non- } \\
\text { mortality group } \\
\text { (years) }\end{array}$ & Outcome \\
\hline \multirow[t]{9}{*}{$\begin{array}{l}\text { Feng } \\
\text { et al. } \\
\text { (14) }\end{array}$} & $\begin{array}{l}\text { Retrospective } \\
\text { cohort study, } \\
\text { multicenter }\end{array}$ & 337 / NA / NA & $16 / N A$ & $321 / N A$ & $\begin{array}{l}\text { HR for risk factors associated } \\
\text { with mortality in patients with } \\
\text { COVID-19 }\end{array}$ \\
\hline & & & & & $\begin{array}{l}\text { - Age over 75: } 6.07(1.65- \\
22.35)^{b}\end{array}$ \\
\hline & & & & & - Leukopenia: $0.66(0.22-1.96)$ \\
\hline & & & & & $\begin{array}{l}\text { - Increased D-dimer: } 3.26 \\
(0.99-10.72)\end{array}$ \\
\hline & & & & & $\begin{array}{l}\text { - Creatine Kinase: } 1.01 \text { (1.01- } \\
1.02)^{b}\end{array}$ \\
\hline & & & & & - LDH: $1.002(1-1.004)^{b}$ \\
\hline & & & & & $\begin{array}{l}\text { - Hypertension: } 1.45(0.42- \\
5.83)\end{array}$ \\
\hline & & & & & $\begin{array}{l}\text { - Cardiovascular disease: } 0.59 \\
(0.1-3.63)\end{array}$ \\
\hline & & & & & - DM: $1.60(0.34-8.16)$ \\
\hline \multirow[t]{3}{*}{$\begin{array}{l}\text { Liang } \\
\text { et al. } \\
\text { (20) }\end{array}$} & $\begin{array}{l}\text { Retrospective } \\
\text { cohort study }\end{array}$ & $1590 / 48.9 \pm 16.3 / 674$ & 50 / NA & 1540 / NA & $\begin{array}{l}\text { HR for risk factors associated } \\
\text { with mortality in patients with } \\
\text { COVID-19 }\end{array}$ \\
\hline & & & & & - Age: $1.04(1.02-1.05)^{b}$ \\
\hline & & & & & $\begin{array}{l}\text { - One or more comorbidities: } \\
2.13(1.39-3.26)^{b}\end{array}$ \\
\hline \multirow[t]{11}{*}{$\begin{array}{l}\text { Shi et } \\
\text { al. } \\
(23)\end{array}$} & $\begin{array}{l}\text { Retrospective } \\
\text { cohort study }\end{array}$ & $416 / 64(21-95)^{a} / 211$ & 57 / NA & 359 / NA & $\begin{array}{l}\text { HR for risk factors associated } \\
\text { with mortality in patients with } \\
\text { COVID-19 from symptom onset }\end{array}$ \\
\hline & & & & & - Age: 1.02 (0.99-1.05) \\
\hline & & & & & $\begin{array}{l}\text { - Cardiovascular disease: } 1.51 \\
(0.7-3.3)\end{array}$ \\
\hline & & & & & $\begin{array}{l}\text { - Cerebrovascular disease: } 1.12 \\
(0.46-2.7)\end{array}$ \\
\hline & & & & & - DM: 0.79 (0.41-1.52) \\
\hline & & & & & - COPD: $0.37(0.04-3.5)$ \\
\hline & & & & & - CKD: $1.1(0.49-2.44)$ \\
\hline & & & & & - Malignancy: 1.75 (0.43-7.16) \\
\hline & & & & & - ARDS: $7.89(3.73-16.66)^{b}$ \\
\hline & & & & & - Increased Cr: $0.59(0.29-1.23)$ \\
\hline & & & & & $\begin{array}{l}\text { - Increased BNP: } 1.16 \text { (0.54- } \\
2.47)\end{array}$ \\
\hline
\end{tabular}




\begin{tabular}{|c|c|c|c|c|c|}
\hline Study & Study design & $\begin{array}{l}\text { Study population (n) / } \\
\text { Mean age } \pm \text { SD } \\
\text { (years) / Female } \\
\text { patients (n) }\end{array}$ & $\begin{array}{l}\text { Study population } \\
\text { (n) / Mean age in } \\
\text { mortality group } \\
\text { (years) }\end{array}$ & $\begin{array}{l}\text { Study population (n) } \\
\text { / Mean age in non- } \\
\text { mortality group } \\
\text { (years) }\end{array}$ & Outcome \\
\hline \multirow[t]{17}{*}{$\begin{array}{l}\text { Cheng } \\
\text { et al. } \\
\text { (11) }\end{array}$} & $\begin{array}{l}\text { Retrospective } \\
\text { cohort study }\end{array}$ & $701 / 63(50-71)^{a} / 334$ & 113 / NA & 588 / NA & $\begin{array}{l}\text { HR for risk factors associated } \\
\text { with mortality in patients with } \\
\text { COVID-19 }\end{array}$ \\
\hline & & & & & $\begin{array}{l}\text { - Age over 65: } 2.43(1.66- \\
3.56)^{b}\end{array}$ \\
\hline & & & & & - Male: $2.15(1.45-3.21)^{b}$ \\
\hline & & & & & $\begin{array}{l}\text { - Severe disease: } 6.1 \text { (3.86- } \\
9.64)^{\mathrm{b}}\end{array}$ \\
\hline & & & & & $\begin{array}{l}\text { - One or more comorbidities: } \\
1.06(0.73-1.54)\end{array}$ \\
\hline & & & & & $\begin{array}{l}\text { - Leukocytosis: } 1.06 \text { (0.73- } \\
1.54)\end{array}$ \\
\hline & & & & & $\begin{array}{l}\text { - Lymphopenia: } 1.02 \text { (0.70- } \\
1.48)\end{array}$ \\
\hline & & & & & $\begin{array}{l}\text { - Proteinuria 1+: } 4.12(1.97- \\
8.62)^{\mathrm{b}}\end{array}$ \\
\hline & & & & & $\begin{array}{l}\text { - PU 2+-3+: } 10.92(5.00- \\
23.86)^{b}\end{array}$ \\
\hline & & & & & $\begin{array}{l}\text { - Hematuria 1+: } 4.64 \text { (2.24- } \\
9.62)^{\mathrm{b}}\end{array}$ \\
\hline & & & & & - HU 2+-3+: $12.2(6.32-23.53)^{b}$ \\
\hline & & & & & $\begin{array}{l}\text { - Increased BUN: } 7.15(4.92- \\
10.39)^{b}\end{array}$ \\
\hline & & & & & $\begin{array}{l}\text { - Increased Cr: } 2.99(2.00- \\
4.47)^{b}\end{array}$ \\
\hline & & & & & $\begin{array}{l}\text { - Peak Cr over } 133 \mu \mathrm{mol} / \mathrm{L}: 5.88 \\
(3.90-8.87)^{\mathrm{b}}\end{array}$ \\
\hline & & & & & - AKI stage 1: $3.51(1.53-8.02)^{b}$ \\
\hline & & & & & $\begin{array}{l}\text { - AKI stage 2: } 6.24(2.73- \\
14.27)^{\mathrm{b}}\end{array}$ \\
\hline & & & & & $\begin{array}{l}\text { - AKI stage 3: } 9.81(5.46- \\
17.65)^{\mathrm{b}}\end{array}$ \\
\hline
\end{tabular}




\begin{tabular}{|c|c|c|c|c|c|}
\hline Study & Study design & $\begin{array}{l}\text { Study population (n) / } \\
\text { Mean age } \pm \text { SD } \\
\text { (years) / Female } \\
\text { patients (n) }\end{array}$ & $\begin{array}{l}\text { Study population } \\
\text { (n) / Mean age in } \\
\text { mortality group } \\
\text { (years) }\end{array}$ & $\begin{array}{l}\text { Study population (n) } \\
\text { / Mean age in non- } \\
\text { mortality group } \\
\text { (years) }\end{array}$ & Outcome \\
\hline \multirow[t]{6}{*}{$\begin{array}{l}\text { Li et } \\
\text { al. } \\
\text { (19) }\end{array}$} & $\begin{array}{l}\text { Retrospective } \\
\text { cohort study }\end{array}$ & 269 / $65(54-72)^{a} / 134$ & 87 / NA & 181 / NA & $\begin{array}{l}\text { HR for risk factors associated } \\
\text { with mortality in severe } \\
\text { patients with COVID-19 }\end{array}$ \\
\hline & & & & & $\begin{array}{l}\text { - Age over 65: } 1.69(1.02- \\
2.59)^{\mathrm{b}}\end{array}$ \\
\hline & & & & & - Male: $1.96(1.24-3.11)^{b}$ \\
\hline & & & & & $\begin{array}{l}\text { - Lymphopenia: } 3.85(2.50- \\
5.93)^{\mathrm{b}}\end{array}$ \\
\hline & & & & & $\begin{array}{l}\text { - Increased LDH: } 3.94(2.48- \\
6.28)^{\mathrm{b}}\end{array}$ \\
\hline & & & & & $\begin{array}{l}\text { - Acute cardiac injury: } 3.89 \\
(2.51-6.01)^{\mathrm{b}}\end{array}$ \\
\hline
\end{tabular}

${ }^{a}$ Median age (interquartile range).

${ }^{b}$ P-value $<0.05$ in the original source.

Abbreviations: SD, standard deviation; HR, hazard ratio (95\% confidence interval); PU, proteinuria; HU, hematuria; BUN, blood urea nitrogen; DM, diabetes mellitus; COPD, chronic obstructive pulmonary disease; CKD, chronic kidney disease; LDH, lactate dehydrogenase; $\mathrm{Cr}$, creatinine; BNP, brain natriuretic peptide; ARDS, acute respiratory distress syndrome; AKI, acute kidney injury

\section{Figures}




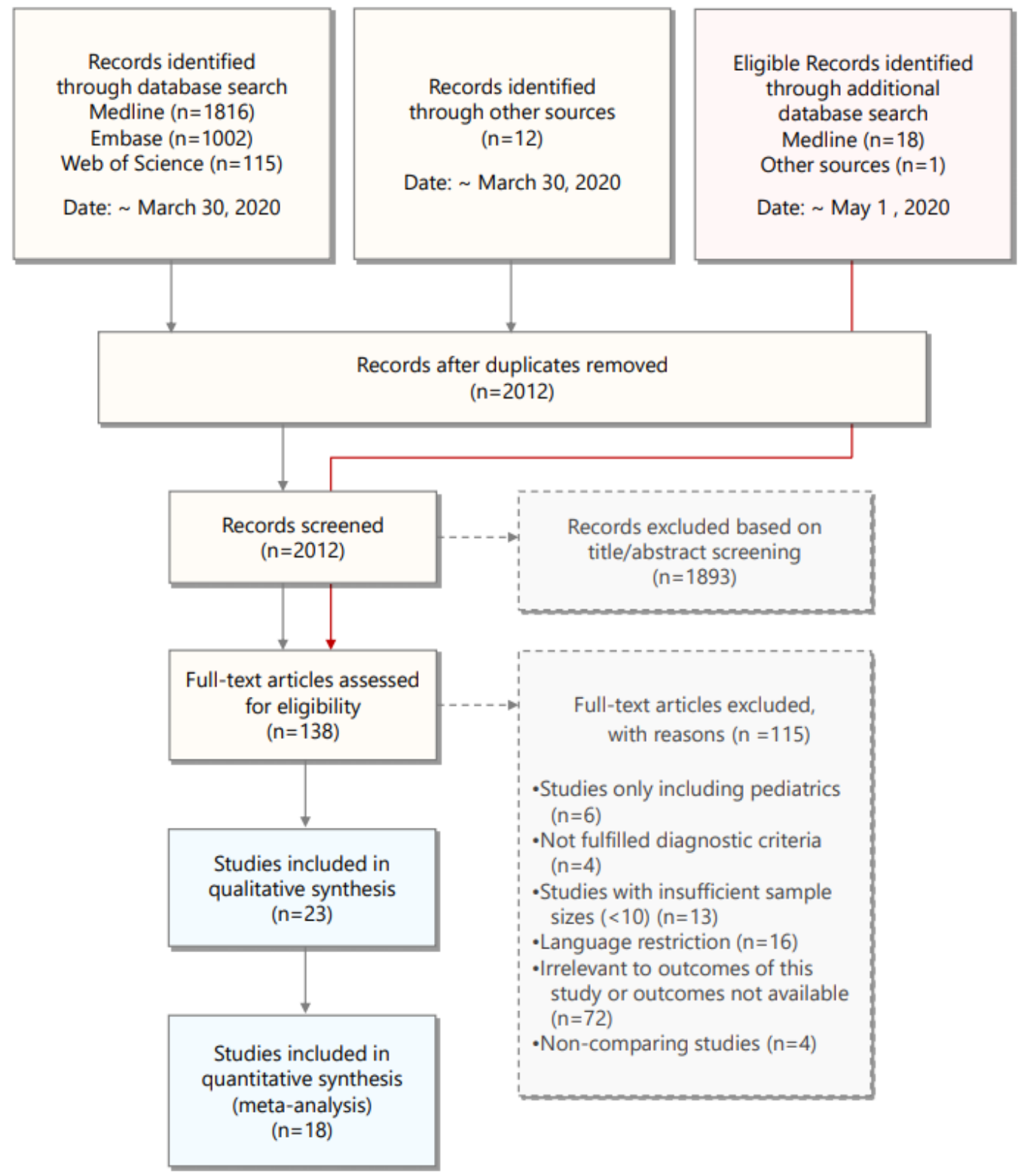

Figure 1

Preferred Reporting Items for Systematic Reviews and Meta-Analyses diagram of study selection. Preferred Reporting Items for Systematic Reviews and Meta-Analyses flow diagram of literature search and study selection for systematic review of mortality in coronavirus disease 2019 patients. 


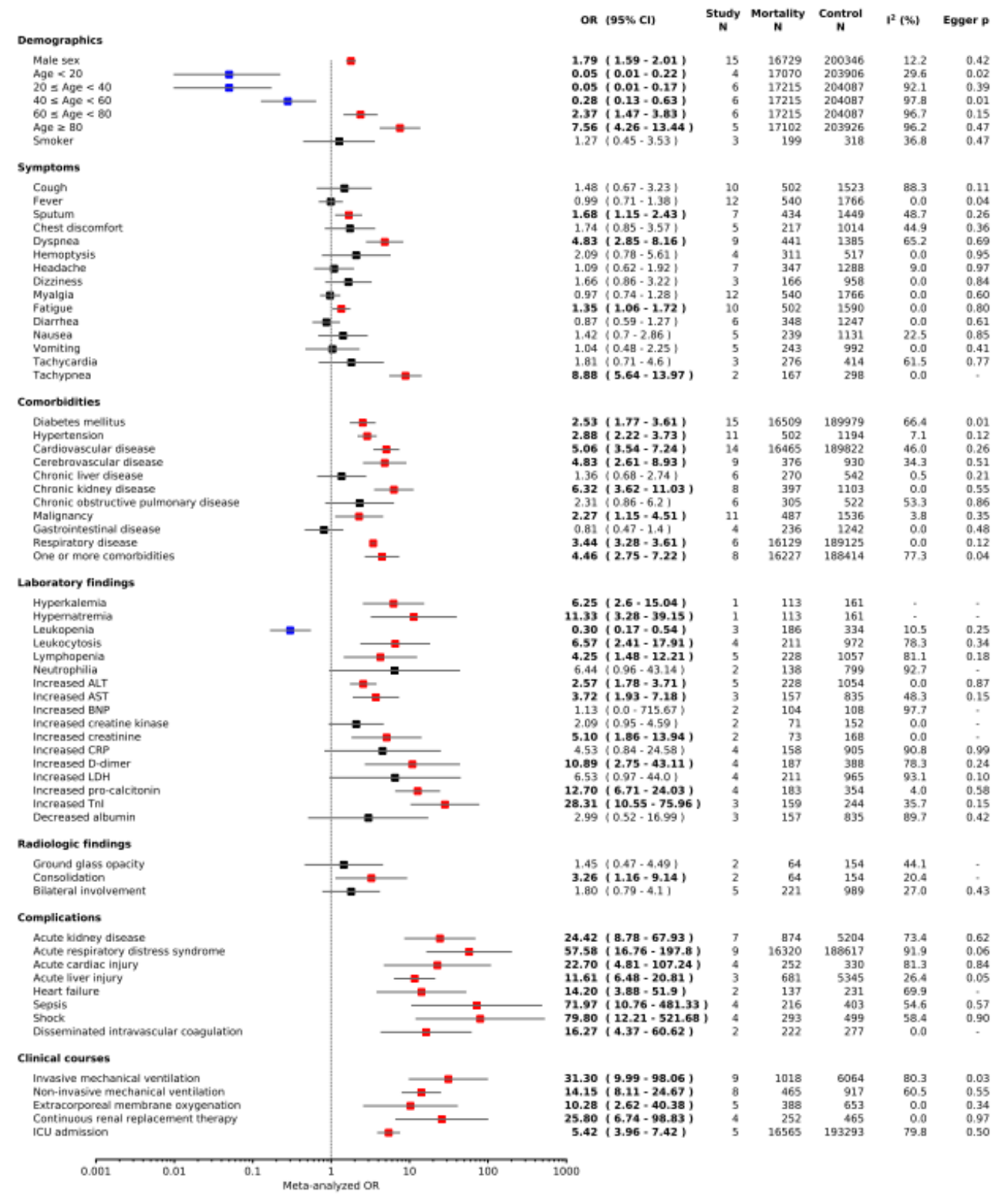

Figure 2

Risk factors associated with mortality in coronavirus disease 2019 Forest plots depict the odds ratio of the demographic, clinical, laboratory, and radiologic findings in mortality patients compared to non-mortality patients. Abbreviations: OR, odds ratio; $95 \% \mathrm{Cl}, 95 \%$ confidence interval; ALT, alanine aminotransferase; AST, aspartate aminotransferase; BNP, brain natriuretic peptide; CRP, c-reactive protein; LDH, lactate dehydrogenase; TnI, troponin I; ICU, intensive care unit

\section{Supplementary Files}

This is a list of supplementary files associated with this preprint. Click to download.

- Supplementarymaterial.docx 